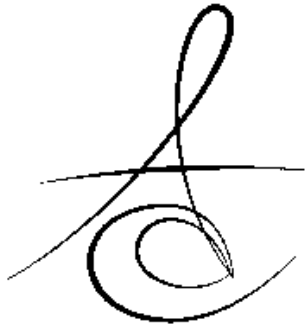

Makale Kodu/Article code: 1942

Makale Gönderilme tarihi: 27.10.2014

Kabul Tarihi: 28.01.2015

\section{OZON TEDAVİSİNİN PERİODONTOLOJİDE KULLANIMI}

THE USE OF OZONE THERAPY IN PERIODONTOLOGY

Dt. Nebi Cansın KARAKAN*

Yrd. Doç. Dr. Aysun AKPINAR*

Dt. Suat Serhan ALTINTEPE DOĞAN*

\section{ÖZET}

Ozon, bakteri, mantar ve virüsler üzerindeki etkisi ve kanama kontrolünde sağladığı yarar nedeniyle tıp alanında uzun süredir kullanılmaktadır. Diş hekimliğinde ise ozon tedavisinin uygulanması ile ilgili bilgiler sınırıdır. İmmünstimülatif, lokal oksijen desteğini arttıran, hemostazı destekleyen ve antimikrobiyal özelliklerinden dolayı diş hekimliğinde kullanımı son yıllarda gündeme gelmiştir. Periodontal başlangıç tedavisinde mekanik tedavi ile birlikte ve cerrahi işlemlerde uygulanmasının klinik sonuçlara ek bir yarar sağlayabileceği düşünülmektedir. Bu derlemede ozonun sahip olduğu özelliklerle birlikte diş hekimliğinde ve özellikle periodontolojide kullanımı, daha önce yapılan çalışmalarla birlikte değerlendirilmiştir.

Anahtar kelimeler: Ozon, periodontoloji, periodontal patojen

\section{ABSTRACT}

Ozone have been used in medical field for a long time due to its benefits against bacteria, fungi, viruses and bleeding control. The information about ozone therapy in dentistry is limited. Immunstimulative, increasing the local oxygen supply, supporting hemostasis and antimicrobial effects of ozone recently raise the use of ozone therapy in dentistry. It have been thought that using ozone with mechanical treatment in initial periodontal therapy and in surgical periodontal therapy may contribute clinical outcomes. In this review with properties of ozone, in dentisry and especially in periodontology it has been evaluated along with past studies.

Key words: Ozone, periodontology, periodontal pathogen.

\section{GİRİ̧̧}

Ozon, oksijenin renksiz bir gaz formudur ve atmosferde bulunmaktadır. Biyosferdeki biyolojik dengenin sağlanmasında önemli rol oynamaktadır. Suyun arıtılmasında ve çeşitli bakteri formlarının öldürülmesinde kullanılmaktadır. Bakteri, mantar, virüs ve parazitlerin öldürülmesinde düşük konsantrasyon da etkin olabilmektedir. ${ }^{1}$

Ozon 3 adet oksijen atomunun birleşmesinden meydana gelmektedir $\left(\mathrm{O}_{3}\right)$. Normal atmosferik oksijenden daha yüksek bir enerji formuna sahiptir $\left(\mathrm{O}_{2}\right)$. Güçlü bir okside edici ajan olduğu belirtilmektedir. $^{2}$ Bir ozon molekülü 3000-10000 klor molekülüne eşdeğerdir ve 3500 kat daha hızlı öldürebilme kapasitesine sahiptir. ${ }^{3}$
Ozon diş hekimliğinde alternatif bir oral antiseptik ajan olarak önerilmektedir. İnsan vücudunda bağışıklık sistemini stimüle eden, analjezik, antihipoksik, detoksik ve antimikrobiyal özellikleri bulunmaktadır. Bu özellikler sonucunda ozonun periodontal doku yıkımını önleyebileceği ve iyileşme sürecini olumlu etkileyebileceği öne sürülmektedir. ${ }^{4,5}$

\section{Ozonun Tarihçesi}

1785 'te Van Marum elektrostatik makinesinde kıvılcımlar oluştuğunda etrafındaki havanın kendine özgü bir kokusunun olduğunu fark etmiştir. 1801'de Cruickshank aynı kokuyu suyun elektrolizi sırasında anot kısmında duymuştur. Sconbein 1840'ta bu maddeyi, Yunancada koklamak anlamına gelen 'Ozein' olarak tanımlamıştır. Ozon 1856'da ameliyathanelerin dezenfeksiyonunda kullanılmıştır. 1857'de Werner Von Siemens bir ozon jeneratörü tasarlamıştır. Daha

${ }^{*}$ Cumhuriyet Üniversitesi Diş Hek. Fak. Periodontoloji AD 
sonraki bu tip jeneratörlerin öncüsü olduğundan piyasadaki bu tip jeneratörlere 'Siemens tipi' ozon jeneratörü denilmiştir. 1860'ta ilk olarak Monako'da ozon jeneratörü bitki tedavisinde kullanılmıştır. 1870'te medikal tedavide ilk olarak Dr. C. Lender tarafından kullanılmıştır. 1901 'de Wiesbaden kentin su şebekesinde ozonu kullanmıştır. 1931'de bir diş hekimi olan E. A. Fisch ozon uygulanmış suyu dental tedavilerde kullanmış ve ileride uygulanacak olan tedavilere öncülük etmiştir. ${ }^{6}$

Ozon gazının diş hekimliğindeki kullanım alanları ile ilgili bilgiler sınırlıdır. Bununla birlikte diş hekimliğinde ozonun ilk kullanımı 1935 yılında rapor edilmiştir. ${ }^{7}$ Hem sıvı hem de gaz haldeki ozonun bakteri, mantar, protozoa ve virüs gibi canlılar üzerinde etkili olabildiği belirtilmiştir. ${ }^{8-10,23}$ Ozonun oksidatif potansiyelinin bakteri ve mantarların hücre membran ve duvarları üzerinde etkili olduğu düşünülmüştür. ${ }^{11}$ Gaz ozonun mikrobisit etkileri sıvı formundan daha fazladır. Bununla birlikte inhale edildiği zaman toksik olabilmesinden dolayı diş hekimliğinde daha çok SıVı formu kullanılmaktadır. Bu nedenle gaz formun daha güvenilir bir biçimde uygulanmasını sağlayan bir sistemin geliştirilmesi gerekmektedir. Aynı zamanda ozonun yağ içine karıştırılan formu da bulunmaktadır. ${ }^{12}$

Medikal olarak kullanılan ozonda saf olarak \% 0,05-5 $\mathrm{O}_{3}$ ve $\%$ 95-99,5 $\mathrm{O}_{2}$ bulunmaktadır. $\mathrm{O}_{3}$ molekülünün kararsız yapısından dolayı karışım hazırlandıktan sonra bekletilmeden kullanılmalıdır. ${ }^{14}$ Buna ek olarak, normal atmosfer havasının bu karışıma girmesi önlenmelidir. Çünkü reaktif özelliğe sahip olan ozonun hava ile teması sonucu, toksik bir gaz olan nitrojen dioksit $\left(\mathrm{N}_{2} \mathrm{O}_{2}\right)$ oluşabilmektedir. ${ }^{40}$

Diş hekimliğinde ozon hemostazı desteklemek, lokal oksijen desteğini arttırmak ve bakteriyel inhibisyon için kullanılmıştır. ${ }^{13}$

Alman bir diş kekimi olan Fritz Kramer'a göre ozon, güçlü bir dezenfektan olarak, kanama kontrolünde ve yara iyileşmesinde kullanılabilmektedir. Dr. Kramer'a göre sıvı formdaki ozon sprey, gargara ve jet irrigasyon olarak uygulanabilmektedir. ${ }^{14}$

Klorheksidin glukonatın mukozal deskuamasyon, bozulmuş yara iyileşmesi, fibroblastlar üzerine sitotoksik etki, dişlerde renklenme ve tat alma duyusunda değişim gibi yan etkilerinin olması, ozonun ağızda antimikrobiyal ajan olarak daha çok kullanımını gündeme getirmektedir. Ozonun hem gaz hem de Sıvı formu patojenler üzerinde etkilidir. ${ }^{15}$

\section{Ozonun Biyolojik Etkileri}

Ozon antimikrobiyal olarak bakteri, mantar ve virüslere karşı etkilidir. Bu etki sitoplazmik membrana zarar vererek organel fonksiyonlarının ve protein sentezinin bozulmasına yol açabilmektedir. Bu etki mikrobiyal hücrelere karşı selektif olup, insandaki hücrelere zarar vermemektedir. antibiyotiklere dirençli bakteri türlerini öldürebilmektedir. ${ }^{16}$

Ozon hücresel ve humoral bağışıklık sistemi üzerinde güçlü bir etkiye sahiptir. Savunma hücrelerinin proliferasyonuna, immünglobulin sentezine ve ayrıca makrofajların fagositoz fonksiyonuna katkı sağlamaktadır. Prostoglandin, lökotrien ve interlökinlerin sentezini arttırarak enflamasyonu azaltıp yara iyileşmesini hızlandırmaktadır. ${ }^{16}$ Bunun sonucunda sitokinler üretilerek diğer immün sistem hücreleri aktif hale gelmektedir. Buna bağlı olarak immün sistem yetmezliği olan hastalarda ozon tedavisinin uygulanabileceği öne sürülmektedir. ${ }^{16}$ Ozon yüksek konsantrasyonda immündepresif, düşük konsantrasyonda ise immünstimülatif etkiye sahiptir. $^{17}$

Ozon dolaşımdaki oksijenin taşınmasına yardımcı olmaktadır. Süperoksit dismutaz, katalaz, dehidrogenaz, glutatyon peroksidaz enzimleri düşük dozdaki ozonla aktive olmaktadır. Bu enzimler organizmayı serbest oksijen radikallerinden korumaktadır. ${ }^{16}$

Hücredeki ribozom ve mitokondri miktarını arttırarak protein sentezini arttırmaktadır. NO (azot oksit) gibi vazodilatatörlerin miktarını arttırarak vazodilatasyona ve ayrıca anjiyogeneziste artışa yol açmaktadır. ${ }^{16}$

Ozon tedavisinin hedefleri; patojenlerin elimine edilmesi, oksijen metabolizmasının restorasyonu, ekolojik bir çevrenin oluşturulması, döngünün hızlanması, humoral antioksidan sistemin stimülasyonu, immün sistemin aktivasyonu olarak belirtilmiştir. ${ }^{17}$

\section{Ozon Toksisitesi}

Ozonun inhalasyonu pulmoner sistem ve diğer organlar için toksik olabilmektedir. Gözler ve akciğerler ozona karşı oldukça duyarlı olan organlardır. ${ }^{39}$ Komplikasyonlar düşük oranda görülmektedir. Epifora, üst solunum yolu irritasyonu, rinit, öksürük, baş ağrısı, nadiren mide bulantısı, kusma, solunum yetmezliği, kan damarlarında ödem, dolaşımın zayıflaması, kalp sorunları ve felç bilinen yan etkilerdir. ${ }^{18}$ Ozonun yüksek oksidatif etkisinden dolayı gazla temas halinde olan tüm materyaller ozona dirençli olmalıdır (cam, silikon, teflon vb.). Bununla birlikte toksikasyon durumunda hasta supin pozisyona getirilir, E vitamini ve $\mathrm{N}$-asetilsistein ile tedavi edilir. ${ }^{19}$ 


\section{Ozonun Endikasyonları}

-Plak ve kontaminasyon kontrolünde, -Kronik ve rekürrent oral lezyonlarda, -Cerrahi işlemlerde,

-Kole hassasiyetinde,

-Periodontal cep, herpetik lezyon, kök kanalı ve kavite sterilizasyonunda,

-Kanal tedavisi görmüş dişlerin beyazlatılmasında,

-Başlangıç çürüklerinin remineralizasyonunda,

-Çürük profilaksi ve önlenmesinde, kullanılmıştır. ${ }^{17,} 20$

\section{Ozonun Kontrendikasyonları}

-Hamilelik,

-Hipertiroidizm,

-Glikoz-6-fosfat dehidrogenaz eksikliği,

-Şiddetli anemi,

-Şiddetli miyasteni,

-Aktif hemoraji,

-Akut alkol intoksikasyonu,

-Yakınlarda geçirilmiş miyokard infarktüsü, olarak belirtilmiştir. ${ }^{21}$

\section{Avantajları}

-Dezenfektan,

-Antienflamatuvar,

-Ağız içi yaralarda hücre içi metabolizmayı uyarması,

-Bölgesel dolaşımı arttırması,

-Rejeneratif süreci uyarması,

-Kapiller kanamalarda homeostasis,

-Ağrısız uygulama, olarak sayılabilir. ${ }^{17}$

\section{Dezavantajları}

-Doz artarsa nadiren görülen toksisite,

-Stabil olmaması,

-Erişim zorluğu, olarak belirtilebilir. ${ }^{17}$

Dental kullanım için ozon üreten uygulamalar

HealOzone (Kavo): Havadaki oksijeni kapalı

bir devre içine alır ve ozona dönüştürür. Negatif basınç yardımıyla ozonu kapalı devre içinde tutar. Uygulanan tedavi sonrasında kalan ozonu yeniden oksijene

dönüştürerek tekrar ortama verir. ${ }^{14}$

OzonyTron (MYMED Gmb H): Tedavi edilecek bölgeye tutulan aletin ince uç kısmından salınan ozon, periodontal cep, kök kanalı gibi ulaşılması zor bölgelere ozon uygulanmasını sağlar. Bu sistemde kapalı devre yoktur. ${ }^{14}$

Product photo (Prozone) (W\&H): Güvenli ve kolay kullanılabilir olması (periodontoloji ve endodontide ayarlanabilen doku uyumlu dozlarının olması) avantajlarıdır. Periodontoloji ve endodontide kullanılan değiştirilebilir plastik uçları sayesinde daha hijyeniktir. ${ }^{14}$

\section{Periodontolojide Ozonun Kullanımı ile İlgili Çalışmalar}

Periodontal hastalık belirli süreçler sonunda aşamalı olarak meydana gelen multifaktöriyel bir hastalıktır. Mikroorganizmalar ve konak yanıtı arasındaki ilişkinin hastalığın temelini oluşturduğu net olarak ortaya konulmuştur. Periodontolojide ozon tedavisinin standart dezenfektan ve antiseptiklere alternatif olarak kullanımı son zamanlarda popüler bir araştırma konusu olarak ortaya çıkmaktadır. Ozonlanmış distile su (4 $\mathrm{mg} / \mathrm{L}$ ), ağız ortamındaki gram negatif, gram pozitif bakterileri candida albicans'ı ve buna ek olarak plak biyofilmindeki bakterileri öldürebilme kapasitesine sahiptir. Ozonun peri-implant hastalıklardaki kullanım alanları ise halen araştırılmaktadır. ${ }^{17}$

Thanomsub ve ark. ${ }^{22} 2002$ 'de ozon tedavisinin hücre gelişimine ve hücre içindeki yapısal değişimlere etkisini bakteriler üzerinde (Escherichia coli, Salmonella sp., Staphylococcus aureus and Bacillus subtilis) incelemişlerdir. Sonuç olarak 0,167 mg/min/L ozonun, $105 \mathrm{cfu} / \mathrm{ml}$ bakteriyle 30 dakika kontamine olmuş suyu steril etmek için kullanılabileceği bulunmuştur. Bakteriyel hücre membranında hasar saptanmıştır. İnterselüler sızıntı ve lizis gözlenmiştir. Ancak 106-107 $\mathrm{cfu} / \mathrm{ml}$ konsantrasyondaki bakteri kültürlerindeki hücrelerin canlılığına bu konsantrasyondaki ozonun anlamlı bir etkisi bulunamamıştır.

Ebensberger ve ark. ${ }^{23}$ 2002'de ozonlanmış suyla irrigasyonun etkisini 23 tam sürmüş ve yeni çekilmiş 3. molar dişlerde değerlendirmişlerdir. Peridontal ligament hücrelerinin proliferasyonu değerlendirilmiştir. Çekilen dişler iki gruba ayrılmıştır. Ozon grubundaki dişler 2 dakika süresince ozonlanmış suyla, kontrol grubundaki dişler ise steril izotonik salin solüsyonuyla irrige edilmiştir. Hücre proliferasyonu immünhisto- kimyasal olarak değerlendirilmiştir. Ozon grubunda salin grubuna göre anlamlı bulunmayan küçük bir fark (\% 7,8-\% 6,6) görülmüştür. Avülse dişlerde 2 dakika süresince non-izotonik ozonlanmış suyla irrigasyonun, periodontal hücreler üzerinde negatif bir etki göstermeden mekanik temizleme yapabildiği, aynı zamanda kök yüzeyinin dekontaminasyonuna yardımcı olduğu belirtilmiştir.

2003'te Holmes ${ }^{24}$, Kavo Healozone'u başlangıç kök çürük lezyonlarının tedavisinde kullanmıştır. Ksilitol, fluorid, çinko, kalsiyum ve fosfat içeren remineralize edici solüsyon, ozon tedavisi sonrasında, yaşları 60-82 arasında değişen 89 hastaya uygulanmıştır. 18 ay sonra ozon grubunda yer alan çürüklerin

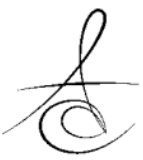


\% 100'ünde gelişim gözlenmiştir. Kontrol grubunda tedavi görmeyen bireylerde, sadece 1 çürük lezyonunda gelişim görülmüştür. Olguların \% 62'sinde herhangi bir gelişim görülmemiş, \% 37'sinde ise daha da kötüye gitmiştir.

Nagayoshi ve ark. ${ }^{9} 2004$ 'te, ozonlanmış suyun, mikroorganizmaların hücre geçirgenliğine ve canlılığına etksini araştırmışlardır. Porphyromonas gingivalis ve Porphyromonas endodontalis gibi gram negatif bakteriler ozona, streptokoklar ve Candida albicanstan daha duyarlı bulunmuştur. Ayrıca ozonlanmış su plak biyofilmindeki bakterilere karşı güçlü bakterisidal etkiye sahiptir. Buna ek olarak ozonlanmış suyun deneysel bakteri plağını in vitro olarak inhibe ettiği belirtilmiştir.

Hems ve Gulabivala ${ }^{25}$ 2005'te ozonun antibakte- Riyel etkisini Enterococcus faecalis test edilen tür olarak kullanılarak araştırmışlardır. Ozonun hem gaz hem de sıvı formu kullanılmıştır. Ozon solüsyonları bu bakteri türüne karşı 240 saniyede antibakteriyel özellik gösterebilmektedir. Sıvı ozon formu biyofilm tabaka- sındaki bakterilere bir dereceye kadar etkili olabilirken gaz formu bu noktada etkisiz kalmaktadır.

Ramzy ve ark. ${ }^{26} 2005$ 'te, agresif periodontitisli 22 hastada periodontal cepleri ozonlu su ile irrige etmiş- lerdir. Bu uygulama haftada $1 \mathrm{kez}$ olmak üzere 4 hafta süresince her seansta en az 5-10 dakika 150 $\mathrm{ml}$ ozonlu suyla gerçekleştirilmiştir. Tüm uygulamalarda steril plastik enjektör ve künt uçlu iğne kullanılmıştır. Cep derinliği, plak indeksi, gingival indeks ve bakteri sayıları tedavi edilen tüm kuadrantlar için SRP+ozon tedavileri öncesi ve sonrasında kaydedilmiş ve bu parametrelerde önemli gelişim görülmüştür.

Huth ve ark. ${ }^{27} 2006$ 'da sivı ozonu gaz ozon, sodyum hipoklorit, klorheksidin diglukonat ve hidrojen peroksite göre daha az yan etkiye sahip olması nedeniyle antiseptik ajan olarak önermişlerdir.

Müller ve ark. ${ }^{28} 2007$ yılında yapmış oldukları çaIışmada fotodinamik terapi (PDT) ile gaz ozonun etkisi ile standart antiseptik ajanlar olan \% 2 klorheksidin, $\% 5$ ve 0,5 hipoklorat solüsyonlarını oral biyofilmde in vitro olarak karşılaştırmışlardır. Actinomyces naes/undii, Veillonella dispar, Fusobacterium nucleatum, Streptococcus sobrinus, Streptococcus oralis ve Candida albicans üzerinde çalışılmıştır. Sistem olarak Kavo Healozone kullanılmıştır. Biyofilm içindeki matrikste yer alan bakterilerin antiseptik ajanlara karşı korunduğu gözlenmiştir. Yalnızca \% 5'lik hipoklorat solüsyonu tüm bakterileri elimine edebilmiştir. Gaz ozon veya PDT biyofilmdeki bakteri sayılarını azaltamamıştır.

Seidler ve ark. ${ }^{16} 2007$ 'de ozonu gingivitisli ve periodontal apseli hastalarda kullanmışlardır. Periodontal apselerde herhangi bir eksudasyon gözlenmemiştir. Gingivitisli hastalarda da subjektif ve objektif olarak gelişim görülmüştür.

Karapetian ve ark. ${ }^{41}$, peri-implantitis hastalarında yaptıkları çalışmada, bakterileri elimine etmede en etkili yöntemin ozon tedavisi olduğunu belirtmişlerdir. Bu çalışmada ozon tedavisi, cerrahi prosedürler ve konvansiyonel yöntemle karşılaştırılmıştır.

Kshitish ve Laxman ${ }^{29} 2010$ 'da generalize kronik periodontitisli 16 hastada yaptıkları çalışmada klorheksidin veya ozonu subgingival irrigasyon için kullanmışlardır (split-mouth therapy). Plak (\% 12), gingival (\% 29) ve kanama (\% 26) indekslerinde ozonla irrigasyonda klorheksidine göre önemli miktarda düşüş gözlenmiştir. Aa sayısında ozon grubunda anlamlı olarak \% 25'lik bir düşüş görülürken, klorheksidin grubunda herhangi bir değişim gözlenmemiştir. Porphyromonas gingivalis ve Tannerella forsythensis miktarlarında herhangi bir değişim görülmemiştir. Ozon anti-fungal etki gösterirken klorheksidin böyle bir etki göstermemiştir. Anti-viral etkilere baktığımızda ise durum bunun tam tersidir. Klorheksidinin anlamlı etkisine rağmen özellikler bakterileri inaktive etmede ozon tedavisi oldukça etkin bulunmuştur.

Fillippi $A .{ }^{17}$, ozonlu suyun oral epitelyal yara iyileşmesini hızlandırdığını gözlemlemiştir.

Huth ve ark. ${ }^{13} 2011$ 'de ozon ve klorheksidinin etkisini periodontal mikroorganizmalar üzerinde karşılaştırmışlardır. Sıvı ozon (20 $\mu \mathrm{g} \mathrm{ml} \mathrm{[-1]),} \mathrm{gaz} \mathrm{ozon} \mathrm{(} \geq 4$ g [-3]) ve \% 2'lik klorheksidin arasında anlamlı farklılıklar görülmemiştir; ancak bu üç uygulama da \% 0,2'lik klorheksidine göre daha etkin bulunmuştur. Ozonun Sıvı ve gaz formlarının periodontal tedavide antiseptik ajan olarak kullanılması için daha çok çalışmaya gereksinim olduğu belirtilmiştir.

Dodwad ve ark. ${ }^{30} 2011$ ' de ozonlu su, \% 0,2'lik klorheksidin ve \% 10 'luk povidon iyodini kronik periodontitisli hastaların oral irrigasyonunda kullanmışlardır. Uygulanan lokal ozonun atravmatik bir antimikrobiyal ajan olduğu, cerrahisiz periodontal tedavilerde hem evde hem de klinikte kullanılabileceği belirtilmiştir.

Eltaş A. ve Yavuzer D. ${ }^{31} 2012$ 'de yaptıkları araştırmada, 15 gingivitis hastasına diş yüzeyi temizliği, bir diğer 15 gingivitis hastasına ise diş yüzeyi temizliğine

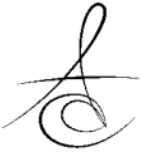


ek olarak ozon uygulaması yapmışlardır. Tedaviden önce ve tedaviden 4 hafta sonra olmak üzere plak indeksi, gingival indeks, sondlamada kanama, sondlama derinliği ve klinik ataçman düzeyi kaydedilmiştir. 4 hafta sonraki ölçümlere bakıldığında plak indeksi, sondlama derinliği ve klinik ataçman düzeyindeki değişimler gruplar arasında anlamlı bir fark göstermemiştir ( $p>0.05)$. Gingival indeks ve sondlamada kanamanın ise ozon grubunda kontrol grubundan daha fazla azaldığı gözlenmiştir $(p<0.05)$. Bu çalışmanın sonucunda diş yüzeyi temizliği+ozon gazı uygulamasının sadece diş yüzeyi temizliğine oranla dişeti enflamasyonunun iyileşmesinde daha etkili olduğu görülmüştür.

Eltaş A. ve Yücel S.E. ${ }^{32}$ 2013'te yaptıkları araştırmada kronik periodontitis hastalarında cerrahi olmayan tedaviye ek olarak uygulanan gaz ozonun klinik periodontal parametrelere ve halitozise etkisini değerlendirmişlerdir. Çalışmada toplam 50 (25 erkek25 kadın) generalize kronik periodontitis hastası yer almıştır. Bu 50 kişi 2 gruba ayrılmıştır. İlk grup ultrasonik aletler ve el aletleri ile tedavi edilmiştir. İkinci gruba buna ek olarak 3. ve 5. günlerde gaz ozon uygulanmıştır. Plak indeksi, sondlamada kanama, klinik ataçman düzeyi ve sondlama derinlikleri kullanılarak periodontal durum değerlendirilmiştir. Halitosis ölçümleri için taşınabilir bir sulfur monitor kullanılmıştır. Tedavi sonrası her iki grupta da tüm klinik periodontal parametelerde gelişim ve halimeter skorlarında düşüş saptanmıştır $(p<0.05)$. Tedavi sonrası gruplar arasında klinik periodontal parametrelerde ve halimeter skorlarında fark olmadığı görülmüştür ( $p>0.05)$. Cerrahi olmayan periodontal tedaviye ilaveten ozon gazı uygulamasının klinik periodontal iyileşmeyi daha fazla artırmadığı ve halimeter skorlarını etkilemediği sonucuna varılmıştır.

Montevecchi ve ark. ${ }^{33} 2013$ 'te ozonlanmış yağ, $\%$ 0,2 klorheksidin diglukonat ve \% 10 povidon iyodini Staphylococcos aureus ve Porphyromonas gingivalise karşı test etmişler ve Ozonlanmış yağın bakteriyel büyümeyi anlamlı olarak daha çok inhibe ettiğini gözlemlemişlerdir $(p<0,01)$.

Özdemir ve ark. $^{34}$ 2013'te yapmış oldukları çalış- mada otojen kemik grefti ile birlikte uygulanan ozonun ratlarda deneysel olarak oluşturulan kafa defekti üzerine etkisini değerlendirmişlerdir. Otojen kemik grefti grubu, otojen kemik grefti+ozon grubu ve tedavi yapılmayan kontrol grubu olmak üzere toplam 3 grup çalışmada yer almıştır. Her grupta 9'ar rat denek olarak kullanulmıştır ve hayvanlar 8 hafta sonra sakrifiye edilmiştir. Toplam kemik alanı ve toplam kemik alanı yüzdesi, greft+ozon grubunda greft grubuna göre anlamlı olarak daha fazladır $(p<0,05)$. Osteoblast sayısı ve yeni kemik formasyonu da benzer şekilde greft+ozon grubunda greft grubuna göre önemli derecede artmıştır.

Yilmaz ve ark. ${ }^{35} 2013$ 'te 30 kronik periodontitis hastasını 3 gruba ayırıp mekanik tedavi, mekanik tedavi+Er-YAG lazer ve mekanik tedavi+gaz ozon uygulamışlar, klinik ve mikrobiyolojik parametrelerde tüm gruplarda benzer gelişimler olduğunu belirtmişlerdir. Ataçman kazancı ve sondlama derinliğindeki azalma lazer grubunda anlamlı olarak diğer gruplara göre daha fazladır. İstatistiksel olarak anlamlı olmasa da zorunlu anaerobik floradaki düşüş en fazla yine lazer grubundadır ve benzer bir düşüş de ozon grubunda gözlenmiştir. Buna göre gaz ozonun da ErYAG lazer kadar mikrobiyolojik açıdan etkin olabildiği belirtilmiştir.

Al Habashneh ve ark. $^{36} 2014$ 'te yapmış oldukları bir çalışmada mekanik tedaviye ek olarak test grubundaki 20 kişiye ozonlu suyla irrigasyon, kontrol grubundaki 21 kişiye ise distile suyla irrigasyon uygulamışlardır. Plak indeksi, gingival indeks, sondlamada kanama, sondlamada cep depinliği, dişeti çekilmesi ve klinik ataçman kaybı başlangıçta ve 3 ay sonra değerlendirilmiştir. Aynı zamanda serumdaki yüksek duyarlılıktaki C-reaktif protein konsantrasyonları da başlangıçta ve 3 ay sonra karşılaştırılmıştır. Gingival indeks dışındaki tüm parametrelerde 3 ay sonra iki grupta da gelişim gözlenmiştir. Buna ek alarak iki grup arasında hiçbir parametre açısından anlamlı bir fark görülmemiştir. Mekanik tedaviye ek olarak kullanılan ozonlu suyla irrigasyonun klinik parametreler ve hs-CRP düzeyi açısından distile suyla irrigasyonla karşılaştırıldığında ek bir yarar sağlamadığı belirtilmiştir.

\section{SONUÇLAR}

Günümüzde periodontal hastalıklarda cerrahi olmayan periodontal tedavi önemli bir yer tutmaktadır. Bu tedavi ise çoğunlukla el aletleri ve ultrasonik aletler ile gerçekleştirilir. Bu uygulamalara ek olarak tedavi etkinliğini arttırmak amacıyla antiseptik, lokal antibiyotik, lazer ve son yıllarda ozon uygulamaları sıklıkla kullanılmaktadır. Daha önce yapılan çalışmalarda ozon uygulamasının önemli periodontal patojen bakteriler arasında yer alan Actinobacillus actinomycetemcomitans ve Porphyromonas gingivalisi

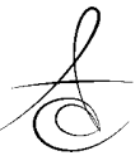


öldürme etkisi rapor edilmiştir. ${ }^{7,8}$ Sigrun ve ark. ${ }^{37}$, kabul edilen periodontopatojenik mikroorganizmalara karşı ozonun güçlü antibakteriyel etkisini rapor etmişler ve periodontal hastalıkların tedavisinde mekanik tedaviyle birlikte kullanılabileceğini belirtmişlerdir. Diğer bir çalışmada ise kronik periodontitisli bireylerde ozon uygulamasının matriks metalloproteinaz üzerindeki etkileri Skurska ve ark. ${ }^{38}$ tarafından araştırımıştır. Bu çalışmada ozon uygulamasının sadece cerrahisiz tedaviye oranla periodontal iyileşmede ek bir faydası olmadığını rapor etmişlerdir. Bu derlemede incelenen çalışmalar göz önüne alındığında ozon uygulamasının en önemli yararının mikrobiyolojik parametreler üzerine olduğu sonucuna varılabilir. Bununla birlikte bazı çalışmalarda bu etki net olarak gözlenmemiştir. ${ }^{13,28}$. Bu derlemede, diş hekimliğinde ve özellikle periodontal başlangıç tedavisinde ozon kullanımının sağladığı klinik yararlar ortaya konmak istenmiştir. Klinik parametreler açısından bakıldığında kontrol gruplarına göre önemli farklar göze çarpmamıştır. Bugüne kadar yapılan çalışmalar göz önüne alındığında özellikle cerrahisiz periodontal tedaviye ek olarak verilen antiseptik, lokal antibiyotik gibi uygulamaların yanı sıra ozonun da ek uygulama olarak kullanılabileceği söylenebilir. Bununla birlikte ozonun dental tedavilerde rutin kullanıma girebilmesi için daha çok çalışmaya gereksinim duyulmaktadır.

\section{KAYNAKLAR}

1. Grootveld M, Baysan A, Siddiqui N, Sim J, Silwood C, Lynch E. History of clinical publications of ozone. In: Lynch $\mathrm{E}$, editor. Ozone: the revolution in dentistry. London: Quintessence Publishing Co; 2004. p. 23-30.

2. Stopka P. Ozon. Progresdent 2003; 6: 8-11.

3. Filippia A. The effect of ozonated water on epithelial wound healing. Douch Dent J 2001; 143: 96-101.

4. Sunnan GV. Ozone in medicine: Overview and future directions. J Adv Med 1988; 1: 159-74.

5. Bocci V. Biological and clinical effects of ozone. Has ozone therapy a future in medicine? $\mathrm{Br}$ J Biomed Sci 1999; 56: 270-9.

6. Sameer M, Monica $M$. Ozone treating dental infections. Ind J Stomatol 2011; 2: 256-9.

7. Azarpazhooh A, Limeback $H$. The application of ozone in dentistry: a systematic review of literature. J Dent 2008; 36: 104-16.
8. Nagayoshi M, Kitamura C, Fukuizumi T, Nishihara $T$, Terashita M. Antimicrobial effect of ozonated water on bacteria invading dentinal tubules. J Endodontics 2004; 30: 778-81.

9. Nagayoshi M, Fukuizumi T, Kitamura C, Yano J, Terashita M, Nishihara T. Efficacy of ozone on survival and permeability of oral microorganisms. Oral Microbiology \& Immunology 2004; 19: 240-6.

10. Arita M, Nagayoshi M, Fukuizumi T, Okinaga T, Masumi T, Morikawa M, Kakinoki $\mathrm{Y}$, Nishihara $\mathrm{T}$. Microbicidal efficacy of ozonated water against Candida albicans adhering to acrylic denture plates. Oral Microbiology \& Immunology 2005; 20: 206-10.

11. Celiberti $P$, Pazera $P$, Lussi $A$. The impact of ozone treatment on enamel physical properties. Am J Dentistry 2006; 19: 67-72.

12. Priyamak AA. Ozone: The Revolution in Dentistry. Copenhagen: Quintessence Publishing; 2004. p. 155-64.

13. Huth KC, Quirling $M$, Lenzke $S$, Paschos $E$, Kamereck K, Brand K, Hickel R, Ilie N. Effectiveness of ozone against periodontal pathogenic microorganisms. Eur J Oral Sci 2011; 119: 204-10.

14. Gupta $G$ ve Mansi B. Ozone therapy in periodontics. J Med Life 2012; 5: 59-67.

15. Baysan A, Whiley RA, Lynch E. Antimicrobial effect of a novel ozone-generating device on microorganisms associated with primary root carious resins in vitro. Caries Res 2000; 34: 498501.

16. Seidler V, Linetskiy I, Hubalkova H. Ozone and Its Usage in General Medicine and Dentistry. A Review Article. Prague Medical Report 2008; 109: 5-13.

17. Srikanth A, Sathish M, Sri Harsha AV. Application of ozone in the treatment of periodontal disease. J Pharm Bioallied Sci Jun 2013; 5: 89-94.

18. Matsumura K, Hyon SH, Nakajima N. Surface modification of polyethylene-co-vinyl alcohol hydroxyapatite immobilization and control of periodontal ligament cells differentiation. Biomaterials 2004; 25: 4817-24.

19. Nogales CG, Ferrari PH, Kantorovich EO. Ozone therapy in medicine and dentistry. J Contemp Dental Pract 2008; 9: 1-9.

20. Baysan A, Lynch E. The use of ozone in dentistry and medicine. Prim Dent Care 2005; 12: 47-52.

21. Nogales CG, Ferrari PA, Kantorovich EO. Ozone

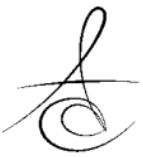


Therapy in Medicine and Dentistry. J Contemp Dent Pract 2008; 9: 75-84.

22. Thanomsub B, Anupunpisit V, Chanphetch $S$, Watcharachaipong T, Poonkhum R, Srisukonth C. Effects of ozone treatment on cell growth and ultrastructural changes in bacteria. J Gen Appl Microbiol 2002; 48: 193-9.

23. Ebensberger U, Pohl Y, Filippi A. PCNA-expression of cementoblasts and fibroblasts on the root surface after extraoral rinsing for decontamination. Dent Traumatol 2002; 18: 262-6.

24. Holmes J. Clinical reversal of root caries using ozone, double-blind, randomised, controlled 18month trial. Gerodontology 2003; 20: 106-14.

25. Hems RS, Gulabivala K, Ng YL, Ready D, Spratt DA. An in vitro evaluation of the ability of ozone to kill a strain of Enterococcus faecalis. Int Endod J 2005; 38: 22-9.

26. Ramzy MI, Gomaa HE, Mostafa MI. Management of aggressive periodontitis using ozonized water. Egypt Med J NRC 2005; 6: 229-45.

27. Huth KC, Jakob FM, Saugel B, Cappello C, Paschos E, Hollweck R, Hickel R, Brand K. Effect of ozone on oral cells compared with established antimicrobials. Eur J Oral Sci 2006; 114: 435-40.

28. Müller P, Guggenheim B, Schmidlin PR. Efficacy of gasiform ozone and photodynamic therapy on a multispecies oral biofilm in vitro. Eur J Oral Sci 2007; 115: 77-80.

29. Kshitish D, Laxman VK. The use of ozonated water and $0.2 \%$ chlorhexidine in the treatment of periodontitis patients: A clinical and microbiologic study. Indian J Dent Res 2010; 21: 341-8.

30. Dodwad V, Gupta S, Kumar K, Sethi M, Masamatti S. Changing paradigm in pocket therapy-ozone versus conventional irrigation. Int J Public Health Dent 2011; 2: 7-12.

31. Eltaş A, Yavuzer D. Dişeti enflamasyonunun tedavisinde gaz ozonun klinik etkilerinin değerlendirilmesi. İnönü Üniversitesi Sağlık Bilimleri Dergisi 2012; 2: 29-33.

32. Eltaş A, Yücel SE. Kronik periodontitis tedavisinde gaz ozon kullanımının halitozise etkisi. İnönü Üniversitesi Sağlık Bilimleri Dergisi 2013; 1: 1-4.

33. Montevecchi M, Dorigo A, Cricca M, Checchi L. Comparison of the antibacterial activity of an ozonated oil with chlorhexidine digluconate and povidone-iodine. A disk diffusion test. New Microbiologica 2013; 36: 289-302.
34. Özdemir $H$, Toker $H$, Balcı $H$, Özer $H$. Effect of ozone therapy on autogenous bone graft healing in calvarial defects: a histologic and histometric study in rats. J Periodont Res 2013; 48: 722-6.

35. Yılmaz S, Algan S, Gürsoy H, Noyan U, Kuru BE, Kadir T. Evaluation of the Clinical and Antimicrobial Effects of the Er:YAG Laser or Topical Gaseous Ozone as Adjuncts to Initial Periodontal Therapy. Photomedicine and Laser Surgery 2013; 31: 293-8.

36. Al Habashneh R, Alsalman W, Khader Y. Ozone as an adjunct to conventional nonsurgical therapy in chronic periodontitis: a randomized controlled clinical trial. J Periodont Res 2014; doi: 10.1111/jre.12177.

37. Sigrun $\mathrm{K}$, İvar SA, Gunnar M. Trend analysis of $\mathrm{O} 3$ and $\mathrm{CO}$ in the period 1980-1996: A threedimensional model study. Journal of Geophysical research 2000; 105: 907-33.

38. Skurska A, Pietruska MD, Paniczko-Drezek A. Evaluation of the influence of ozonotherapy on the clinical parameters and MMP levels in patients with chronic and aggressive periodontitis. Advances in Medical Sciences 2010; 55: 297-307.

39. Yeğin Z, Tosun G. Diş Hekimliğinde Ozon ve Kullanım Alanları. Atatürk Üniversitesi Diş Hek. Fak. Dergisi 2013; 23: 116-22.

40. Korkmaz H, Küçükkolbaşı H. Diş Hekimliğinde Ozon Uygulamaları. Atatürk Üniversitesi Diş Hek Fak Derg 2013; 7: 125-34.

41. Karapetian VE, Neugebauer J, Clausnitzer CE, Zoller JE. Comparison of Different Periimplantitis Treatment Methods. [Last accessed on 2013 January 29]. Available from: http://www.helbo.at/ datasheets/poster_karapetian_0304.pdf .

\section{Yazışma Adresi}

Dt. Nebi Cansın KARAKAN

Cumhuriyet Üniversitesi

Diş Hek. Fak.

Periodontoloji AD

SİVAS

Tel.: 2191010/2706/2753

e-mail: cansinkarakan@hotmail.com 